\title{
COUNTER-TERRORIST SECURITY: THE EXAMPLE OF THE SPECIAL POWERS OF THE POLISH SPECIAL SERVICES IN THE FIELD OF SURVEILLANCE OF FOREIGN NATIONALS
}

The research question presented in this paper concerns selected anti-terrorist security issues, in the context of the special powers of the Polish special services in the field of surveillance of foreign nationals. The issue of anti-terrorist security was reduced to the issues connected with the assessment of the effectiveness of combating terrorism by the Polish special services, and to the assessment of potential costs related to the possibility of violating the privacy of Polish citizens and foreign nationals when certain types of surveillance activities are used. Therefore, it should be recognized that an important problem taken up in this analysis is the relationship between the sphere of security and the private sphere, which is connected with the rights and freedoms of an individual in a democratic state governed by the rule of law.

In criminal policy related to the combating of certain types of crime, it is important to indicate: (1) the legal interest to be protected, (2) the degree of protection of such interest, and (3) the means to be used to protect the interest. In a democratic state governed by the rule of law, criminal policy must not only be an instrument to exercise power but should also be a means of protecting interests that are valuable to society. This general assumption inevitably leads to a conflict between different types of interests - between security and the rights and freedoms of individuals. This, however, does not change the fact that, in a democratic state governed by the rule of law, emphasis is placed on the protection of rights related to individual freedoms (cf. Gruszecka, 2012; Kulesza, 2014: 87-110; Tarapata, 2016; Kulesza, 2017: 95-112).

When terrorist threats are invoked in today's democratic states governed by the rule of law, there is a visible tendency to abuse the interest of security to justify legislation. There is dangerous tendency to overuse the penalization of certain actions and the creation of oversight mechanisms, even when there is only a potential threat that these actions might infringe any interests. In a democracy, penalization and oversight mechanisms should be applied only when the threat is real and imminent, rather than only potential and abstract. Therefore, any solutions which encroach on the freedom and rights of an individual should be considered in accordance with the principle of proportionality (cf. the judgment of the Constitutional Tribunal of April 26, 1995, file ref. K 11/94, 1995; Dukiet-Nagórska, 2010; Hryniewicz, 2012; Brodzisz, 2013: 17-41; Hryniewicz-Lach, 2015; Rychlewska, 2016: 131-149; Kulesza, 2017). 
The main objective of the analysis contained in this paper is to present the consequences of introducing legal changes to give the special services the power to use special types of surveillance on foreign nationals. In the analysis, particular attention was paid to the remit and powers of one of the special services, namely the Internal Security Agency (Polish: Agencja Bezpieczeństwa Wewnętrznego, the ABW). Due to the need to narrow down the scope of the identified research issue, the following research questions are presented in the paper: (1) To what extent can mechanisms in Polish law influence the effectiveness of combating terrorism by the Polish special services? (2) To what extent can mechanisms in Polish law in the field of combating terrorism violate the rights and freedoms of Polish citizens and foreign nationals?

The analysis presented in this paper is mainly of an indicative nature. The legal and institutional approach was used to analyze the endeavors and powers of the Polish special services in the context of the surveillance activities they perform on both Polish and foreign nationals. On the other hand, the analysis of individual legal solutions was based on a dogmatic and doctrinal interpretation, and a pro-constitutional interpretation of the provisions of substantive and procedural criminal law (cf. Wronkowska, Ziembiński, 1997: 147-179; Wronkowska, 2005: 76-91; Korybski, Leszczyński, 2015: 150-165; Nowacki, Tabor, 2016: 293-312; Rychlewska, 2016: 131-149).

\section{CHARACTERISTICS OF STATUTORY CHANGES RELATED TO THE SPECIAL SERVICES IN 2015-2018}

After the change of government in 2015, rapid changes took place in the field of substantive criminal law, procedural criminal law and acts governing the activities of the special services in Poland. In the period 2015-2018, changes were made to existing laws or new ones were introduced regarding: (1) tapping and recording conversations (under criminal procedural law), (2) the subject of operational oversight (under individual laws governing the operation of the special services and the police), (3) new acts classified as "terrorist offenses" (under substantive criminal law), (4) special powers given to Polish counterintelligence in connection with combating and counteracting terrorist activity (under the new Act on Anti-Terrorist Activities (hereafter the AntiTerrorism Act or ATA), and (5) extension of the remit of Polish civilian counterintelligence to include combating crimes against the Judiciary (e.g. false testimony and false accusations).

During this period, the Polish government also worked on changes concerning the activities of Polish civil intelligence and counterintelligence. Analysts indicated that a consolidation of these two types of special services into a single National Security Agency (Agencja Bezpieczeństwa Narodowego) was very likely. Analysts also indicated that the new service would be given new powers regarding operational oversight, while at the same time real judicial oversight over them would be minimized. In connection with the projected direction of changes in the special services, it was assumed that the ministries would also be reorganized in such a way that a new ministry would be established (the Ministry of Security) which would become a center for governing all the special services, even the military ones (cf. Miłosz, 2017; Rosicki, 
2017; Stankiewicz, 2017b). The fact that this did not occur is due to several factors, including: (1) the focus of the ruling coalition on extensive changes to the judiciary at various levels (Constitutional Tribunal, Supreme Court, common courts of all instances), (2) rivalry, mainly within the party and between individual members of the government, and (3) changes in the management positions of the special services (cf. Czuchnowski, 2017a; Czuchnowski, 2017b; Kacprzak, Zawadka, 2017).

In the period 2015-2018, no organizational irregularities or dysfunctions within Polish counterintelligence and civil intelligence were eliminated, despite them being discussed earlier in the press and academic literature. Therefore, there were no positive changes to solve the problems in Polish counterintelligence and intelligence activity. In particular, attention should be paid to the Internal Security Agency (the ABW), as it is currently responsible for coordinating all activities in the field of combating terrorist threats (cf. Articles 5, 7, 8 and 17 of the ATA). When analyzing the performance of the ABW in the period 2015-2018, the problems from which it had suffered in the past continued: (1) 'politicization' and 'political partisanship,' (2) the instrumental treatment of the ABW as a part of the patronage system, (3) inappropriate selection of staff, which led to the employment of personnel who did not meet the requirements related to competence and the appropriate attitude towards serving the state, (4) lack of reliable and transparent advancement mechanisms, (5) lack of an appropriate system of training and courses within the service, and (6) excessively broad remit, while simultaneously duplicating responsibilities held by other Polish special services (cf. Czuchnowski 2016; Rosicki, 2016: 165-176; Czuchnowski, 2017c; Kacprzak, 2017; Są zawiadomit prokurature..., 2017; Stankiewicz, 2017a; Pietrzak, 2018).

\section{CHARACTERISTICS OF STATUTORY CHANGES TO THE POWERS OF THE SPECIAL SERVICES IN COMBATING TERRORISM}

\section{Gathering information on terrorism}

Interestingly, even before the legislative changes of 2016, the Internal Security Agency was the main entity dealing with combating terrorist threats (cf. AoISA\&FIA; Makarski, 2010: 101-112; Obuchowicz, 2014: 275-280). The Anti-Terrorism Act, on the other hand, designated the ABW as the main coordinator of anti-terrorist policy and gave it many powers to use various measures on Polish citizens and foreign nationals (cf. Jałoszewski, Kondzińska, 2016). In connection with the prevention of terrorist incidents, the Head of the ABW was granted the power to maintain an inventory (database) of information on both Polish and foreign nationals. The inventory includes, in particular, the following categories of individuals: (1) persons engaging in activities on behalf of terrorist organizations or organizations associated with terrorist activities, (2) persons who are members of terrorist organizations or organizations associated with terrorist activities, (3) wanted persons engaging in terrorist activities or suspected of committing terrorist offenses, (4) persons reasonably suspected of engaging in activities leading to terrorist offenses, (5) persons constituting a threat to the security of 
civil aviation, (6) persons participating in terrorist training, and (7) persons undertaking travel for the purpose of committing terrorist offenses (Article 6.1.1-4 of the ATA). The Anti-Terrorism Act indicates that there must be four different sets of data that can be collected in a single register, the database. Moreover, there is no indication that all data must be covert, so, at least in theory, this information does not have to be kept fully confidential, for example information on persons wanted under the European Arrest Warrant (cf. Gabriel-Węglowski, 2018: 70-72).

A separate category of data is collected to identify citizens of other countries by individual services, including the special services. Under the Anti-Terrorism Act, officers of the Internal Security Agency, the Police and the Border Guard, with respect to persons who are not Polish citizens, have been granted the following powers: (1) fingerprinting, (2) facial image preservation, and (3) non-invasive collection of biological material (for DNA profiling purposes). This data may be obtained by individual services when: (1) there is doubt as to the identity of the person, (2) the person is suspected of illegally crossing the Polish border, (3) there is doubt as to the declared purpose of stay in Poland, (4) there is a suspicion of intent to illegally stay on Polish territory, (5) there is a suspected connection between the person and a terrorist event, or (6) there is a suspicion that the person could have participated in terrorist training (Article 10.1.1-5 of the ATA). According to the ATA, the entity which has at its disposal the collected information is the Commander in Chief of the Police, within the framework of the existing system of police databases (Article 10.2-5 of the ATA). It seems that these regulations significantly interfere with the procedural position of foreign nationals, depriving them of equal treatment under substantive and procedural criminal law. For example, it should be pointed out that the premise of a suspected connection between a person and a terrorist event is sufficient for the Polish legislator to treat a foreigner as a suspect under procedural criminal law, which results in the obligation to undergo, for example, external and other examinations (Article 74.3 Code of Criminal Procedure (CCP)). However, under the ATA, if there is a suspicion that a terrorist offense has been committed, if it is required by the (preparatory) proceedings, the decision to press charges may be drawn up on the basis of information obtained by operational-and-intelligence activities, including surveillance activities specified in the ATA (Article 26.1 of the ATA). The latter solution is somewhat dubious due to the infringement of the rights and freedoms of an individual inherent in a democratic state governed by the rule of law, as the legislator has also included the possibility of depriving both Polish citizens and foreign nationals of liberty for a period of more than forty-eight hours. Moreover, information from operational-and-intelligence activities, including from surveillance activities specified in the Anti-Terrorism Act, is a sufficient premise for this type of deprivation of liberty.

\section{A terrorist offense}

The term terrorist offense was introduced into the Criminal Law Act in 2004. The introduction of a legal definition of a terrorist offense resulted from the adaptation of Polish legislation to the content and requirements of the framework decision of the 
Council of the European Union on combating terrorism (Council Framework Decision, 2002/475/JHA; Report from the Commission, 2007). According to the solutions included in Article 115.20 of the Criminal Law Act, a terrorist offense is a prohibited act committed in order to: (1) seriously intimidate many persons, (2) coerce a public authority of Poland or another state, or an authority of an international organization, to undertake or refrain from certain activities, or (3) cause serious disturbances in the political system or economy of Poland, another state or an international organization. Even the threat of committing a terrorist offense will also constitute such an act. However, an important formal premise is the reservation that the prohibited act should be subject to a maximum of 5 years' imprisonment by way of punishment (Article 115.20 of the Criminal Code (CC); Rosicki, 2015: 93-96).

It should be noted that the construction of the aforementioned provision means that even if at least one motivational premise and a general formal premise exist, any prohibited act indicated in criminal law will be terrorist offense. It seems that this provision does not meet the basic principles of legislation in a democratic state governed by the rule of law because of: (1) difficulty in unambiguously identifying a legal interest whose protection would be valuable for society (the provision uses an unspecified object of the offense), (2) identification of the types of acts which are prohibited mainly due to the abstract exposure of the legal interest to danger, and (3) the inclusion by the legislator of a large number of vague and ambiguous constituent features of an offense. The group of vague features includes, among others, the following: (1) serious intimidation, (2) many people (the legal doctrine is not clear and at least three interpretative positions can be given), (3) serious disturbances of the political system, and (4) serious disturbance of the economy of an international organization (cf. Rosicki, 2015: 93-96; Kozłowska-Kalisz, 2018: 388-389; Gabriel-Węglowski, 2018: 53-58).

\section{Anti-terrorist and counter-terrorist activities}

The concepts of anti-terrorist and counter-terrorist activities have been introduced by the provisions of the Anti-Terrorism Act (Article 2.1 and 2 of the ATA). By anti-terrorist activities, the legislator understands a specific type of event that should be prevented by public administrative authorities. The designated events are events of a terrorist nature. At this point one should note that the legislator has introduced the term terrorist event in addition to the previously accepted term terrorist offense. A terrorist event is one in which there is a suspicion that it occurred as a result of a terrorist offense, or in which there is the threat of a terrorist offense (Article 2.7 of the ATA). It can therefore be said that an event of a terrorist nature is determined by the presumption of an effect and by the presumption of a threat.

In the case of counter-terrorist activities, the legislator wanted to point to a specific type of activity directed against perpetrators, as well as individuals preparing or assisting in committing a terrorist offense. These activities should be carried out to eliminate the immediate danger to the life, health or liberty of people or property by using specialized forces and methods and by applying specialized tactics (Article 2.2. of the ATA). 
The problems of interpretation affect the issues related to the application of special types of measures towards Polish and foreign nationals. For example, the mere fact that an event is defined as a terrorist event is the basis for the Head of the ABW to maintain a list of persons related to terrorism and to collect data on them (Article 6 of the ATA). On the other hand, the Head of the ABW can use special surveillance measures with regard to foreign nationals in order to collect intelligence about, prevent or combat terrorist offenses, if there is merely a concern as to the possibility of these people conducting terrorist activities (Article 9 of the ATA). Meanwhile, the application of a special procedure for pressing charges and pre-trial detention of Polish citizens and foreigners is based on the suspicion of having committed a terrorist offense, the justification for which may be information obtained only by means of operational-andintelligence activities, including surveillance activities specified in the Anti-Terrorism Act (Article 26 of the ATA).

\section{CHARACTERISTICS OF THE POWERS OF THE SPECIAL SERVICES IN THE FIELD OF SURVEILLANCE OF FOREIGN NATIONALS IN CONNECTION WITH A TERRORIST THREAT}

\section{General characteristics of surveillance by the special services}

On the basis of the information submitted by the Public Prosecutor General to the legislative authority, it should be pointed out that all authorized services submitted a total of 6,035 requests to order the tapping and recording of conversations, or requests to administer operational oversight in 2016. Out of a total of 6,035 requests, the court granted permission to $97.5 \%$, which means that only a small number of cases were considered unfounded. It should be noted that, as a general rule, oversight in Poland is administered in two stages, i.e. first at the level of the prosecutor's office, and then at the level of the court. Consequently, we are dealing with both prosecutor and court oversight of requests for the surveillance of individuals (Attorney General's information, 2017).

The service responsible for the largest number of requests is the Police (almost $80 \%$ ), followed by the Border Guard (6.8\%), Internal Security Agency (4.3\%), Central Anti-Corruption Bureau (almost 3.6\%), Military Police (2.7\%), and other services (less than 1\%). The Police is the largest service, within the framework of which there is also a special uniformed formation, the Police Central Bureau of Investigation, which deals with the most dangerous crimes, hence the highest number of requests related to tapping and recording conversations, and to operational oversight. It is worth noting that there is a significant number of these requests submitted by the Military Police, which, apart from the Police, ranks third in terms of the number of requests (following the Polish civilian counterintelligence service and the service combating corruption). Moreover, it should be noted that the Police submitted the highest number of requests rejected by the prosecutor's office and the court in 2016 (125 cases), which may be due to the very large number of requests they submitted. If the ratio of rejected requests to 
the number of requests submitted by a particular organization is assessed, first place is taken by the Military Police (5.9\%), followed by the Military Counterintelligence Service (2.9\%), the Police (almost 2.6\%), the Border Guard (2.1\%), the Internal Security Agency (1.5\%) and the Central Anti-Corruption Bureau (1.3\%) (Attorney General's information, 2017; Rosicki, 2017).

It is worth noting that academic, popular science and journalistic analyses on the level of surveillance in Poland indicate a high level of involvement of the Polish special services in this type of operational oversight. Moreover, it should be emphasized that statutory changes on the basis of the so-called surveillance act (full name: Act on the Amendment of the Act on Police and Certain Other Acts, Journal of Laws 2016, item 147) and the Anti-Terrorism Act violate the principles of a democratic state governed by the rule of law in the area of individual rights and freedoms (cf. Rosicki, 2014: 63-75; Gierak-Onoszko, 2016: 10-13; Wniosek Rzecznika Praw Obywatelskich z dnia 18 lutego 2016 r. (sygn. akt K 9/16), 2016; Pytlakowski, 2017: 22-25; Rok $z$ ustawa inwigilacyjna, 2017).

\section{Procedure for the surveillance of foreigners}

According to the Anti-Terrorism Act, the entity responsible for initiating the procedure to undertake surveillance activities with regard to foreign nationals is the Head of the ABW (Article 9.1 of the ATA). Under specific arrangements, various surveillance activities with regard to foreign nationals may be undertaken only in order to prevent or combat terrorist offenses, and when there is a fear that foreign nationals may carry out terrorist activities. This provision indicates that two simultaneous conditions must be fulfilled regarding the objective of the operation of the $\mathrm{ABW}$ (preventing and combating a specific type of crime), and the possibility of a given foreign national carrying out terrorist activities. These conditions are made up of terms specified from a legal point of view, as well as of subject-matter constituent features for which there is no legal basis, e.g. in the constituent features of prohibited acts or in legal definitions. An example of a phrasing for which there is no legal definition is terrorist activities, which constitute one of the parallel conditions for the use of surveillance activities by the Head of the ABW. The carrying out of terrorist activities as a constituent feature did not previously feature in the provisions of criminal law, and the closest equivalent of this term was prohibited activities, which were constituent features of selected crimes against peace and humanity, and constituent features of war crimes. Other similar phrasings include: activities for the benefit of foreign intelligence (in the framework of selected offenses against the State), organizing and directing foreign intelligence activities (in the framework of selected offenses against the State), participating in an organized group or association with the purpose of committing a criminal offense, including participating in groups whose purpose is committing a terrorist offense (in the framework of selected offenses against public order).

Therefore, a surveillance procedure applied to a foreign national must be initiated by an order from the Head of the ABW. According to the law, this order, together with its justification, must be immediately forwarded to the Minister Coordinator of the 
Special Services, if a Coordinator has been appointed, and also to the Public Prosecutor General, who, according to the current legal situation, is also the Minister of Justice (Article 9.4 of the ATA). The Public Prosecutor General may order the discontinuation of surveillance activities against a foreign national (Article 9.4 ATA). It is worth pointing out that this procedure lacks a judicial oversight mechanism, as provided for under the Act on the Internal Security Agency and Foreign Intelligence Agency itself, regarding the application of operational oversight measures (cf. Rogalski, 2017: 92-120). According to this procedure, surveillance activities may be carried out for a maximum period of three months but may be extended under the conditions laid down in the Act on the Internal Security Agency and Foreign Intelligence Agency (Article 9.1 of the ATA; Article 27 of the AoISA\&FIA). The results of the work in this period, obtained by means of the various types of surveillance, should be communicated as information to the Public Prosecutor General as soon as they have been completed (Article 9.6 ATA). It is worth noting at this point that the Polish legislator once again abandoned oversight mechanisms through the courts, as is the norm in democratic states governed by the rule of law - it is only the Public Prosecutor General, not the court, that decides on the scope and manner of using information gained from the surveillance of a foreign national (Article 9.7. of the ATA).

If the materials provided by the Head of the ABW do not contain any evidence of an offense or are not important for state security, the Public Prosecutor General orders the destruction of the materials resulting from surveillance activities (Article 9.8 of the ATA). Following the above, the Head of the ABW, immediately after the order from the Public Prosecutor General, must perform a witnessed and recorded destruction of the material (Article 9.9 of the ATA).

The main problems with the application of the procedure are as follows: (1) the wide range of activities of the $\mathrm{ABW}$, including intelligence, prevention and combating of terrorist offenses; (2) the use of a vague term, i.e. concerns about the possibility of conducting terrorist activities; and (3) the lack of a statutory definition of the term foreign national.

What is worth noting is the fairly broad range of purposes for which surveillance means can be used with respect to foreign nationals. This covers the collection of intelligence, prevention and combating terrorist offenses. Therefore, we are dealing with preventive, operational-and-intelligence, and procedural powers held by the ABW. On the other hand, limiting surveillance activities to one type of offense, i.e. terrorist offenses, may be misleading, which results from previous remarks concerning the understanding of the content of the legal definition of this type of offense. It should also be added that the vague phrase concerns about the possibility of conducting terrorist activities, contrary to what M. Gabriel-Węglowski claims, does not effectively limit the use of surveillance activities (Gabriel-Węglowski, 2018: 76-77). The term concern, from the point of view of the special services, rather than from the normative point of view, could be used liberally - all the more so as surveillance measures applied on the basis of the Anti-Terrorism Act, contrary to the measures within the framework of operational oversight specified in the Act on the Internal Security Agency and Foreign Intelligence Agencies, are not limited by the principle of subsidiarity. The principle of subsidiarity would require the verification of surveillance requests from the point 
of view of whether other measures have proved to be ineffective or of no use to the special services (cf. Article 9.1 of the ATA; Article 27.1 of the AoISA\&FIA). It should therefore be assumed that solutions concerning the surveillance of foreign nationals are a departure from this principle, which is also one of the elements of the protection of privacy in democratic states governed by the rule of law.

The Anti-Terrorism Act does not have its own definition of the term foreign national; hence, in an attempt to define the scope of persons to whom the surveillance is to apply, the contents of the Act on Foreign Nationals must be used. According to the above Act, a foreign national is any person who does not have Polish citizenship (Art. 3.2 of the Act on Foreign Nationals). However, it should be added that "a Polish citizen who simultaneously holds the citizenship of another state has the same rights and obligations towards the Republic of Poland as a person who holds Polish citizenship exclusively." As a result, a Polish national "may not invoke before the authorities of the Republic of Poland, with legal effect, the citizenship of another state and the rights and obligations arising therefrom" (Article 3.1-2 of the Act on Polish Citizenship). According to this interpretation, it is impossible to apply special types of surveillance measures to persons holding Polish citizenship and, at the same time, citizenship of another state. However, in the absence of sufficient oversight of surveillance measures at the level of the prosecution and of the court that may be used by the special services, including in the case of instrumental use of the law, such limitations might be not enforced. One may also consider the problem of differentiating people on the basis of their citizenship, as this cannot be used to limit the rights which are included, for example, in the Convention for the Protection of Human Rights and Fundamental Freedoms (ECHR) (cf. Case of Szabó and Vissy v. Hungary, 2016; Bychawska-Siniarska, 2017). However, what is certain is that any surveillance in a democratic state governed by the rule of law should be overseen by a court or an authority exercising judicial power. The case that is described by this paper shows that this is not present (cf. Case of Malone v. The United Kingdom, 1984).

\section{Scope of surveillance activities}

The types of surveillance activities which under special conditions may be applied to foreign nationals include: (1) obtaining and recording the content of conversations made using technical means, including using telecommunications networks; (2) obtaining and preserving images or sounds of persons from premises, means of transport or places other than public spaces; (3) obtaining and recording the content of correspondence, including correspondence carried out by means of electronic communication; (4) obtaining and recording data contained on IT data carriers, telecommunication terminal equipment, IT and ICT systems; and (5) accessing and controlling the content of letters or parcels (Article 9.1.1-5 of the ATA).

The enumerated surveillance measures are the same as the operational oversight measures specified by the legislator in the Act on the Internal Security Agency and the Intelligence Agency (Article 27.6.1-5 of the AoISA\&FIA; Bożek et al., 2014: 125-132; Rogalski, 2017: 92-120). At this point, one may ask oneself for what purpose the legis- 
lator repeated the list of types of surveillance measures which had already been defined in another act. The mere fact that the measures had a different personal scope does not seem to be sufficient to explain this. There are two reasons for this, which include justifications (1) of a political nature, and (2) of a functional nature. In the first case, attention should be paid to the unconstitutionality of the scope and basis of applying operational oversight by the special services in Poland and the possible negative effects of negating this scope and basis. However, the risk of negating the legal basis for the application of operational oversight is currently only theoretical given the changes in the law on the judiciary, resulting in dysfunctional constitutional control in the period in question. As a result of the statutory changes, there are no real mechanisms for the independent examination of compliance of legal acts with the Constitution in Poland. As a consequence, the fundamental principles of the democratic state governed by the rule of law are violated (cf. Opinion..., 2016; Szuleka, Wolny, Szwed, 2016; Gersdorf, 2018a; Gersdorf, 2018b; Żaczkiewicz-Zborska, 2018). In the latter case, i.e. where there is a functional justification, attention should be paid to the desire to conceal surveillance powers already in the hands of the special services, referred to as operational oversight. This takes place alongside the simultaneous liberalization of surveillance oversight mechanisms, and thus alongside the resulting more liberal use of them by the special services. The rationale for a functional approach is as follows: (1) the lack of judicial oversight of the initial application of surveillance measures, (2) the possibility of carrying out surveillance throughout the full period, even after the conditions for its application have ceased, and (3) strengthening the position of the Public Prosecutor General at the expense of judicial oversight (the Public Prosecutor General decides on the scope and use of surveillance material) (cf. Gabriel-Węglowski, 2018: 78-91).

$$
* * *
$$

The main purpose of the analysis in this paper was to indicate the consequences of introducing legal changes concerning the powers of the special services, with particular reference to the powers of the Internal Security Agency. The focus was the powers of the Internal Security Agency regarding the application of special types of surveillance activities with respect to persons who do not have Polish citizenship, under the Anti-Terrorist Act, with the presentation of the broader legal context. In order to give a more in-depth analysis of the subject at hand, the paper asked the following research questions: (1) To what extent can mechanisms in Polish law influence the effectiveness of combating terrorism by the Polish special services? (2) To what extent can mechanisms in Polish law in the field of combating terrorism violate the rights and freedoms of Polish citizens and foreign nationals? The individual questions were linked to the following conclusions:

\section{Conclusions related to the first question:}

Legal mechanisms regarding the surveillance powers of the special services under the so-called Surveillance Act and the Anti-Terrorism Act should be considered helpful in improving the effectiveness of obtaining information on terrorist events and terrorist offenses. There are at least two main problems to be addressed regarding the expan- 
sion of the ABW's remit: (1) broader powers to apply operational oversight measures in the absence of appropriate mechanisms to oversee their application, and (2) broader powers to apply operational oversight measures in the absence of gains in organizational efficiency. In the first case, an increase in the ABW's powers is at the expense of rights and freedoms, thus at the expense of principles attributed to a democratic state governed by the rule of law, including the principle of proportionality. In the latter case, the range of activities and powers of the $\mathrm{ABW}$ is broadened on the grounds of new legal solutions. However, no attempt is made to increase its internal efficiency. This lack of efficiency is associated with the high level of 'politicization' and 'political partisanship' of the ABW, inappropriate selection of staff, and the lack of an appropriate training system combined with a lack of adequate supervision. This, together with an unreasonably broad remit, leads to the inappropriate use of the powers of the ABW in the fight against crimes against national security and terrorism.

\section{Conclusions related to the second question:}

It should be noted that changes ensuing from the so-called Surveillance Act of 2016 do not meet the recommendations issued by the Constitutional Tribunal to the legislator in connection with the recognition that individual provisions in the field of operational oversight, applied by individual services, are unconstitutional. This means that surveillance activities (activities within the scope of operational oversight) on the grounds of the aforementioned Act could violate the rights and freedoms of both Polish and foreign nationals. The ABW still enjoys significant and unjustified access to telecommunications data, the collection of which is not subject to restrictions, which are the basis for recording telephone conversations, for example. The oversight mechanism related to the procedure for obtaining consent for particular activities in the field of operational oversight and telecommunications data should be considered as fictitious. Thereby, the transparency of the ABW's activities in this area continues to remain low.

In the case of the Anti-Terrorism Act, the additional powers in the field of surveillance of foreign nationals are in principle a repetition of those contained in the Act on the Internal Security Agency and the Foreign Intelligence Agency with respect to all persons. The difference is that covert activities applied by the ABW in connection with combating terrorism are subject to even less oversight than in the case of the ABW's general remit. The legislator opted not to require judicial oversight of the initial applications for surveillance of foreign nationals. This has to be considered as a violation of the fundamental principles of a democratic state governed by the rule of law, including the principle of proportionality. Moreover, it should be noted that the surveillance of foreign nationals is not limited by the principle of subsidiarity, which can also be considered a violation of the principles of a democratic state governed by the rule of law.

Moreover, the introduction of a special procedure for presenting charges and for pre-trial detention of Polish citizens and persons who do not have Polish citizenship, based on materials obtained on the basis of operational oversight, including surveillance activities, set out in the Anti-Terrorism Act, should be considered at least constitutionally dubious. This may be considered a further breach of the principles of a democratic state governed by the rule of law, including the principle of proportionality. 


\section{REFERENCES}

Attorney General's information on the petitions concerned with the institution of monitoring and recording conversations, and petitions for the institution of operational control in 2016 (Document no. 530) (2017), Senate of the Republic of Poland, Warsaw.

Bożek M., Czuryk M., Karpiuk M., Kostrubiec J. (2014), Stużby specjalne w strukturze władz publicznych. Zagadnienia prawnoustrojowe, Warszawa.

Brodzisz Z. (2013), Ochrona prywatności w procesie karnym - porównanie regulacji prawnych polskich i niemieckich, "Prokuratura i Prawo", No. 4.

Bychawska-Siniarska D. (2017), Bezprawna inwigilacja narusza prywatność, http://prawo.gazeta prawna.pl/artykuly/1019628, bezprawna-inwigilacja-narusza-prywatnosc.html,komentarzenajnowsze, 1 (14.12.2017).

Case of Malone v. The United Kingdom, No. 8691/79, ECtHR, Judgment, 02.08.1984.

Case of Szabó and Vissy v. Hungary, No. 37138/14, ECtHR (Fourth Section), Judgment, 12.01.2016.

Council Framework Decision (2002/475/JHA) of 13 June 2002 on combating terrorism, Official Journal of the European Communities L 164/3-7.

Czuchnowski W. (2016), Nowe ABW na tropie starego ABW. Szukaja wpadek poprzedników, http://wyborcza.pl/1,75398,19636636,nowe-abw-na-tropie-starego-abw-szukaja-wpadekpoprzednikow.html (17.02.2016).

Czuchnowski W. (2017a), Najpierw sady, potem czystka w stużbach. A jesienia wielka operacja przeciw wrogom PiS, http://wyborcza.pl/7,75398,21478761,najpierw-sady-potem-czystkaw-sluzbach-a-jesienia-wielka-operacja.html (15.04.2017).

Czuchnowski W. (2017b), Specukład w PiS. Jak służby Kamińskiego i Macierewicza walcza o władzę, http://wyborcza.pl/magazyn/7,124059,22601603,specuklad-w-pis-jak-sluzby-kaminskiegoi-macierewicza.html (10.12.2017).

Czuchnowski W. (2017c), W półtora roku z kaprala na pułkownika. Szef ABW awansował o 14 stopni w 18 miesięcy, http://wyborcza.pl/7,75398,22079127,w-poltora-roku-z-kaprala-na-pulkownika-szef-abw-awansowal-o.html (25.07.2017).

Dukiet-Nagórska T. (2010), Zasada proporcjonalności w prawie karnym, Warszawa.

Gabriel-Węglowski M. (2018), Działania antyterrorystyczne. Komentarz, Warszawa.

Gersdorf M. (2018a), Opinia do projektu ustawy o zmianie ustawy przepisy wprowadzajace ustawe o organizacji i trybie postepowania przed Trybunatem Konstytucyjnym oraz ustawę o statusie sędziów Trybunału Konstytucyjnego, Sąd Najwyższy, Warszawa.

Gersdorf M. (2018b), Opinia do zgłoszonego w dniu 22 marca 2017 r. przez posłów Klubu Parlamentarnego „Prawo i Sprawiedliwość” projektu ,ustawy o zmianie ustawy z dnia 27 lipca 2001 r. - Prawo o ustroju sądów powszechnych oraz ustawy z dnia 8 grudnia 2017 roku o Sądzie Najwyższym”, Sąd Najwyższy, Warszawa.

Gierak-Onoszko J. (2016), Tajemnica? Publiczna!, „Polityka”, No. 8.

Gruszecka D. (2012), Ochrona dobra prawnego na przedpolu jego naruszenia: Analiza karnistyczna, Warszawa.

Hryniewicz E. (2012), Przestępstwa abstrakcyjnego i konkretnego zagrożenia dóbr prawnych, Warszawa.

Hryniewicz-Lach E. (2015), Kara kryminalna w świetle Konstytucji RP, Warszawa.

Jałoszewski M., Kondzińska A. (2016), Agencja bierze wszystko, „Gazeta Wyborcza”, 24.03.2016. 
Kacprzak I. (2017), Przyspieszony awans szefa ABW?, http://www.rp.pl/Sluzby-mundurowe/ 307049890-Przyspieszony-awans-szefa-ABW.html\&cid=44\&template=restricted (05.07.2017).

Kacprzak I., Zawadka G. (2017), Wielkie czyszczenie w ABW, http://www.rp.pl/Sluzbymundurowe/170929071-Wielkie-czyszczenie-w-ABW.html\&cid=44\&template=restricted (15.10.2017).

Korybski A., Leszczyński L. (2015), Stanowienie i stosowanie prawa. Elementy teorii, Warszawa.

Kozłowska-Kalisz (2017), Przestępstwo o charakterze terrorystycznym, in: Kodeks karny. Komentarz, (eds.) M. Mozgowa et al., Warszawa.

Kulesza J. (2014), Zarys teorii kryminalizacji, „Prokuratura i Prawo”, No. 11-12.

Kulesza J. (2017), Problemy teorii kryminalizacji. Studium z zakres prawa karnego i konstytucyjnego, Łódź.

Makarski A. (2010), Centrum Antyterrorystyczne Agencji Bezpieczeństwa Wewnętrznego. Geneza, zasady działania oraz doświadczenia po pierwszym roku funkcjonowania, „Przegląd Bezpieczeństwa Wewnętrznego", No. 2.

Miłosz M. (2017), Ministerstwo Ochrony Państwa już sieje popłoch. Stużby specjalne w jednym superresorcie, http://www.gazetaprawna.pl/artykuly/1051456,superresort-skupiajacy-sluzbyspecjalne-grozny-dla-mon.html (19.06.2017).

Mozgowa M. et al. (eds.) (2017), Kodeks karny. Komentarz, Warszawa.

Nowacki J., Tabor Z. (2016), Wstęp do prawoznawstwa, Warszawa.

Obuchowicz M. (2014), Pięć lat funkcjonowania Centrum Antyterrorystycznego ABW, „Przegląd Bezpieczeństwa Wewnętrznego", No. 10.

Opaliński B., Rogalski M., Szustakiewicz P. (eds.) (2017), Ustawa o Agencji Bezpieczeństwa Wewnętrznego oraz Agencji Wywiadu. Komentarz, Warszawa.

Opinion on amendments to the Act of 25 June 2015 on the Constitutional Tribunal of Poland, adopted by the Venice Commission at its 106th Plenary Session (2016), Venice, 11-12 March 2016.

Pietrzak L. (2018), Rosyjscy szpiedzy w Polsce! Zinfiltrowali nasze stużby cywilne i wojskowe, https://warszawskagazeta.pl/kraj/item/5377-rosyjscy-szpiedzy-w-polsce-zinfiltrowalinasze-sluzby-cywilne-i-wojskowe (12.01.2018).

Pytlakowski P. (2017), Imperium inwigilacji, „Polityka”, No. 36.

Report from the Commission based on Article 11 of the Council Framework Decision of 13 June 2002 on combating terrorism \{SEC(2007) 1463\} (2007), Brussels, 6.11.2007 COM(2007) 681 final.

Rogalski M. (2017), Zarzadzenie kontroli operacyjnej i zasady jej prowadzenia, in: Ustawa o Agencji Bezpieczeństwa Wewnętrznego oraz Agencji Wywiadu. Komentarz, (eds.) B. Opaliński, M. Rogalski, P. Szustakiewicz, Warszawa.

Rok z ustawa inwigilacyjna. Co się zmieniło? Czy było się czego bać? (2017), Fundacja Panoptykon, Warszawa.

Rosicki R. (2014), Surveillance and data retention in Poland, „Public Policy and Economic Development", No. 2.

Rosicki R. (2015), Information and anti-terrorist security of Poland. A critical analysis exemplified with the tasks and activity of the Internal Security Agency, „Studia Politologiczne”, Vol. 38.

Rosicki R. (2016), Poland's internal security as exemplified by the tasks and activities of the Internal Security Agency in the period 2007-2015, „Przegląd Politologiczny”, No. 1.

Rosicki R. (2017), Special Services and Surveillance of Citizens In Poland (2015-2017), Working Paper, No. 1 [DOI: 10.13140/RG.2.2.18880.23042]. 
Rychlewska A. (2016), O gwarancyjnym modelu wykładni prokonstytucyjnej przepisów typizujących czyny zabronione pod groźba kary, „Czasopismo Prawa Karnego i Nauk Penalnych”, No. 3.

Sąd zawiadomit prokurature o wyczynach oficera $A B W$ (2017), http://bialystok.wyborcza.pl/ bialystok/7,35241,22269432,sad-zawiadomil-prokurature-o-wyczynach-oficera-abw.html (23.08.2017).

Stankiewicz A. (2017a), Grzegorz Małecki: nie jesteśmy gotowi na obrone przed terrorystami, https:// wiadomosci.onet.pl/tylko-w-onecie/grzegorz-malecki-nie-jestesmy-gotowi-na-obroneprzed-terrorystami/wc77wj9 (29.052017).

Stankiewicz A. (2017b), Superminister of Security, http://wiadomosci.onet.pl/tylko-w-onecie /super minister-od-bezpieczenstwa/v7k36cl (18.03.2018).

Szuleka M., Wolny M., Szwed M. (2016), Kryzys konstytucyjny w Polsce 2015-2016, Helsińska Fundacja Praw Człowieka, Warszawa.

Tarapata Sz. (2016), Dobro prawne w strukturze przestepstwa. Analiza teoretyczna i dogmatyczna, Warszawa.

Ustawa z dnia 24 maja 2002 r. o Agencji Bezpieczeństwa Wewnętrznego oraz Agencji Wywiadu, Dz. U. 2002, Nr 74, poz. 676 ze zm. [abbrv. AoISA\&FIA].

Ustawa z dnia 10 czerwca 2016 r. o działaniach antyterrorystycznych, Dz. U. 2016, poz. 904 [abbrv. ATA].

Ustawa z dnia 6 czerwca 1997 r. - Kodeks karny, (Dz. U. 1997, Nr 88, poz. 553 ze zm. [abbrv. CC].

Ustawa z dnia 12 grudnia 2013 r. o cudzoziemcach, Dz. U. 2013, poz. 1650 ze zm. [abbrv. FN].

Ustawa z dnia 2 kwietnia 2009 r. o obywatelstwie polskim, Dz. U. 2012, poz. 161 ze zm. [abbrv. $\mathrm{PC}]$.

Ustawa z dnia 6 czerwca 1997 r. - Kodeks postępowania karnego, Dz. U. 1997, poz. 555 ze zm. [abbrv. CCP].

Ustawa z 15 stycznia 2016 r. o zmianie ustawy o Policji oraz niektórych innych ustaw (Dz. U. 2016, poz. 147).

Wniosek Rzecznika Praw Obywatelskich z dnia 18 lutego 2016 r. (sygn. akt K 9/16).

Wronkowska S. (2005), Podstawowe pojęcia prawa i prawoznawstwa, Poznań.

Wronkowska S., Ziembiński Z. (1997), Zarys teorii prawa, Poznań.

Wyrok Trybunału Konstytucyjnego z 26 kwietnia 1995 r. (sygn. akt K 11/94).

Żaczkiewicz-Zborska K. (2018), TK wydaje o połowę mniej wyroków niż w latach poprzednich, http://www.lex.pl/czytaj/-/artykul/tk-wydaje-o-polowe-mniej-wyrokow-niz-w-latach-poprzednich (28.03.2018).

\begin{abstract}
The material scope of the analysis presented in this paper refers to special powers held by the Polish special services with respect to the surveillance of foreign nationals in connection with terrorist threats and terrorist offenses. This paper connects the issue of anti-terrorist measures with the assessment of the effectiveness of the Polish special services and with the assessment of potential social costs, which are related to the increase in the powers held by these services in the field of surveillance of Polish citizens and foreign nationals. The analysis of the powers of the special services focuses on the powers of one of the counterintelligence services, i.e. the Internal Security Agency (Polish: ABW).
\end{abstract}


The purpose of this paper is to indicate the consequences of the introduction of legal changes concerning the powers held by the special services in the scope of applying particular types of surveillance activities (operational-and-intelligence activities). It poses the following research questions: (1) To what extent can mechanisms in Polish law influence the effectiveness of combating terrorism by the Polish special services? (2) To what extent can mechanisms in Polish law in the field of combating terrorism violate the rights and freedoms of Polish citizens and foreign nationals? In order to answer the research questions, the activities and powers of Polish special services were analyzed from a legal and institutional point of view. On the other hand, to analyze legal regulations related to surveillance, the author applied a dogmatic and doctrinal interpretation and a pro-constitutional interpretation of the provisions of criminal law.

Keywords: anti-terrorist safety, information security, terrorist offenses, surveillance, the special services

\section{BEZPIECZEŃSTWO ANTYTERRORYSTYCZNE NA PRZYKLADZIE SZCZEGÓLNYCH UPRAWNIEŃ POLSKICH SŁUŻB SPECJALNYCH W ZAKRESIE INWIGILACJI CUDZOZIEMCÓW}

\section{STRESZCZENIE}

Zakres przedmiotowy analizy w tekście dotyczy szczególnego rodzaju uprawnień polskich służb specjalnych w zakresie inwigilacji cudzoziemców w związku ze zwalczaniem zagrożeń terrorystycznych i przestępstw o charakterze terrorystycznym. Problematyka bezpieczeństwa antyterrorystycznego powiązana została w tekście $\mathrm{z}$ oceną efektywności działania polskich służb specjalnych oraz z oceną potencjalnych kosztów społecznych, które wiążą się ze zwiększeniem uprawnień tych służb w zakresie inwigilacji obywateli polskich i cudzoziemców. W przypadku analizy uprawnień służb specjalnych skupiono się na uprawnieniach jednej ze służb kontrwywiadowczych, czyli Agencji Bezpieczeństwa Wewnętrznego (Pol. ABW).

Celem jest wskazanie konsekwencji, jakie wiążą się z wprowadzeniem zmian prawnych dotyczących uprawnień służb specjalnych w zakresie stosowania szczególnego rodzaju czynności inwigilacyjnych (czynności operacyjno-rozpoznawczych). W tekście zaprezentowano następujące pytania badawcze: (1) W jakim stopniu rozwiązania w polskim prawie wpływać mogą na efektywność zwalczania przestępczości terrorystycznej przez polskie służby specjalne?, (2) W jakim stopniu rozwiązania w polskim prawie, w zakresie zwalczania przestępczości terrorystycznej, mogą naruszać prawa i wolności obywateli polskich oraz cudzoziemców? W celu udzielania odpowiedzi na pytania badawcze wykorzystano ujęcie prawno-instytucjonalne w zakresie analizy zadań i uprawnień polskich służb specjalnych. Natomiast do analizy regulacji prawnych związanych z inwigilacją zastosowano interpretację dogmatyczno-doktrynalną oraz interpretację prokonstytucyjną przepisów prawa karnego.

Słowa kluczowe: bezpieczeństwo antyterrorystyczne, bezpieczeństwo informacji, przestępstwa o charakterze terrorystycznym, inwigilacja, służby specjalne 
